\title{
Determination of Inorganic Ions in Ethanol Fuel by Capillary Electrophoresis
}

\author{
Rodrigo A. A. Munoz, Eduardo M. Richter, Dosil P. de Jesus, Claudimir L. do Lago and \\ Lúcio Angnes*
}

Instituto de Química, Universidade de São Paulo, Av. Prof. Lineu Prestes, 748, 05508-900 São Paulo - SP, Brazil

\begin{abstract}
O controle do conteúdo de íons inorgânicos em combustíveis veiculares tem uma importante função na manutenção do motor. Um método novo e versátil para análise rápida de íons em etanol é apresentado. Eletroforese capilar foi utilizada para quantificar cátions (sódio, potássio, cálcio, magnésio e amônio) e ânions (sulfato, cloreto e nitrato). A injeção direta da amostra no capilar apresentou falta de repetibilidade nos resultados. A evaporação prévia do etanol, seguida pela resuspensão do material residual, levou a resultados confiáveis. Os limites de detecção para os oito íons estiveram na faixa de 0,06 a $0,18 \mathrm{mg} \mathrm{L}^{-1}$. Limites de detecção inferiores podem ser obtidos com o aumento do tempo de injeção e/ou da pressão de injeção.
\end{abstract}

The control of the content of inorganic ions in vehicular fuels plays an important role in the engine maintenance. A novel and versatile methodology to carry out rapid analysis of ions in ethanol is presented. Capillary electrophoresis was used to quantify cations (sodium, potassium, calcium, magnesium, and ammonium) and anions (sulfate, chloride, and nitrate). The injection of the sample directly in the capillary shows some lack of repeatability of the results. The prior evaporation of the ethanol, followed by a re-suspension of the residual material, leads to reliable results. The detection limits of the eight ions range between 0.06 and $0.18 \mathrm{mg} \mathrm{L}^{-1}$. Lower detection limits could be attained by increasing the injection time and/or the injection pressure.

Keywords: ethanol fuel, inorganic ions, capillary electrophoresis

\section{Introduction}

In Brazil, ethanol as a fuel is obtained from the fermentation of sugar cane, and this process is now well established. With an annual production of $13 \times 10^{9} \mathrm{~L}$ in $2002,{ }^{1}$ ethanol is predominantly consumed as vehicular fuel, both in the anhydrous form, (mixed with gasoline, which enhances the octane number and acts as antiknocking agent), or in the hydrated form (94\% ethanol). The contamination of the ethanol fuel with metal ions such as copper, iron, and sodium and inorganic anions such as chloride and sulfate can affect engine performance, since salts and sediments that are formed can block the nozzles and induce corrosion in the vehicle components in contact with the fuel. ${ }^{2}$

Almeida et $a l .^{3}$ and Oliveira et al. ${ }^{4}$ described methodologies for sodium determination in ethanol fuel using flame photometry. The determination of metals in ethanol fuel by electrothermal atomic absorption spectrometry ${ }^{5-7}$ is well established and flame atomic

*e-mail: luangnes@iq.usp.br absorption spectrometry can be used for same determinations after preconcentration. ${ }^{8,9}$ Anodic stripping voltammetry was used for zinc determination. ${ }^{10}$ The Brazilian Petroleum National Agency - ANP (Agência Nacional de Petróleo) establishes upper limit of 1, 4, and $2 \mathrm{mg} / \mathrm{kg}$ for chloride, sulfate, and sodium ions, respectively, in hydrated ethanol fuel. ${ }^{11}$ The recommended techniques for the determination of chloride, sulfate, and sodium ions in this fuel sample are, respectively, potentiometry, precipitation titration, and atomic emission spectroscopy. Ion chromatography (IC) is also described by ANP for the simultaneous determination of chloride and sulfate. ${ }^{11}$ Methods for the determination of cations and anions in ethanol fuel are scarcely found in the literature. Piatnicki et al. ${ }^{12}$ showed preliminary results for the determination of chloride and sulfate in ethanol fuel by using capillary electrophoresis, without prior treatment of the sample. Capillary electrophoresis (CE) is a powerful technique that provides high-resolution efficiency and is a good alternative for the simultaneous quantification of several anions and cations. Capillary electrophoresis with contactless conductivity detection (CCD) was applied 
successfully for the determination of ions in rainwater ${ }^{13}$ and in human serum samples. ${ }^{14}$ The main advantages of CE over IC are the lower cost and shorter time of analysis.

In this work, we describe a method based on capillary zone electrophoresis with CCD for the determination of some cations and anions in ethanol fuel.

\section{Experimental}

\section{Reagents and samples}

All reagents were of analytical grade. 2-[Nmorpholino]ethanosulfonic acid (MES), L-histidine (HIS), N-cetyl-N-N-N-trimethylammonium bromide (CTAB), lactic acid, $\mathrm{NH}_{4} \mathrm{Cl}, \mathrm{KCl}, \mathrm{NaCl}, \mathrm{LiOH}, \mathrm{CaCl}_{2}, \mathrm{MgCl}_{2}, \mathrm{NaNO}_{3}$, and $\mathrm{Na}_{2} \mathrm{SO}_{4}$ were purchased from Merck (Darmstadt, Germany). Running buffer and individual stock solutions (2000 $\mathrm{mg} \mathrm{L}^{-1}$ of each cation) were prepared with $18 \mathrm{M} \Omega . \mathrm{cm}$ deionized water (NANOpure UV, Barnstead/Thermolyne Co., Dubuque, Iowa, USA). The lithium and lactate (2000 $\mathrm{mg} \mathrm{L}^{-1}$ ) stock solutions were prepared by the total neutralization of $\mathrm{LiOH}$ and lactic acid with $\mathrm{HCl}$ and $\mathrm{NaOH}$, respectively. Standard solutions with mixtures of cations and anions were prepared by dilution of individual stock solutions until the desired concentration. Bromide in CTAB was replaced by hydroxide (CTAH) using an anion exchanger column (Merck, Darmstadt, Germany). The running buffer for anions analysis contained $20 \mathrm{mmol} \mathrm{L}^{-1}$ MES/HIS and $0.2 \mathrm{mmol} \mathrm{L}{ }^{-1} \mathrm{CTAH} .{ }^{13}$ The CTAH was added to promote the inversion of the direction of the electroosmotic flow. For cations, $20 \mathrm{mmol} \mathrm{L}^{-1} \mathrm{HIS} / \mathrm{lactic}$ acid and $2.5 \mathrm{mmol} \mathrm{L}^{-1}$ 18-crown-6-ether ${ }^{14}$ solution was used. The crown-ether was added to delay the $\mathrm{K}^{+}$peak, otherwise superimposed to the $\mathrm{NH}_{4}^{+}$peak.

Two hydrated ethanol fuel samples (A and B) were purchased at different local fuel station in the city of São Paulo and were stored in glass bottles carefully cleaned with ultra pure water.

\section{Equipment}

A home made capillary electrophoresis equipment was used for the analysis. ${ }^{15,16}$ A Pentium ${ }^{\circledR} 133 \mathrm{MHz}$ microcomputer controls the instrumental parameters and the acquisition of the signals from the CCD operating at $600 \mathrm{kHz}$. The detector was placed at $10 \mathrm{~cm}$ from the end of the capillary. The samples were injected by gravity from a height of $100 \mathrm{~mm}$ for $30 \mathrm{~s}$ into a $75 \mathrm{~mm}$ inner diameter and $50 \mathrm{~cm}$ length fused-silica capillary (Agilent Technologies, São Paulo, Brazil). The applied voltages were -15 and +15 $\mathrm{kV}$ for anion and cation determinations, respectively.

\section{Sample preparation}

$1 \mathrm{~mL}$ of sample was completely evaporated ${ }^{17,18}$ in a 10 $\mathrm{mL}$ glass beaker on a hot plate at $90^{\circ} \mathrm{C}$ and then an equal volume of ultra pure water was added. This pretreatment takes 2 min and can be carried out for several samples simultaneously. The utilized beakers were previously maintained overnight filled with deionised water. This procedure avoids contamination of the sample during the alcohol evaporation process.

\section{Results and Discussion}

The injection of untreated samples directly into the capillary was tested without success. The responses obtained in this way showed a marked lack of repeatability, probably due to the adsorption of organic substances present in the samples on the internal capillary wall. In addition, the difference in conductivity between the samples and the buffer solution generated different migration times for the analytes. The evaporation of the ethanol allowed overcoming both problems. Table 1 contains the migration times of all ions in standard solutions and pretreated samples. The relative standard deviations $(n=4)$ are below $0.8 \%$, which indicates excellent repeatability of the signals.

Table 1. Migration times measured for the ions in standard solutions and ethanol fuel samples $(n=4)$

\begin{tabular}{lcc}
\hline Analytes & Standards $(\min )$ & Samples $(\mathrm{min})$ \\
\hline $\mathrm{Cl}^{-}$ & $3.11 \pm 0.02$ & $3.11 \pm 0.02$ \\
$\mathrm{NO}_{3}^{-}$ & $3.29 \pm 0.02$ & $3.33 \pm 0.02$ \\
$\mathrm{SO}_{4}^{2-}$ & $3.44 \pm 0.03$ & $3.46 \pm 0.02$ \\
$\mathrm{Lactate}^{2-}$ & $4.69 \pm 0.04$ & $4.77 \pm 0.03$ \\
$\mathrm{NH}_{4}^{+}$ & $3.53 \pm 0.02$ & $3.55 \pm 0.01$ \\
$\mathrm{~K}^{+}$ & $3.80 \pm 0.02$ & $3.82 \pm 0.01$ \\
$\mathrm{Na}^{+}$ & $4.65 \pm 0.01$ & $4.69 \pm 0.01$ \\
$\mathrm{Ca}^{2+}$ & $5.11 \pm 0.02$ & $5.16 \pm 0.02$ \\
$\mathrm{Mg}^{2+}$ & $5.31 \pm 0.03$ & $5.36 \pm 0.02$ \\
$\mathrm{Li}^{+}$ & $5.66 \pm 0.01$ & $5.71 \pm 0.02$ \\
\hline
\end{tabular}

Figure 1 shows the electropherogram of ethanol fuel (a) and the same sample with addition of $1.94 \mathrm{mg} \mathrm{L}^{-1}$ of each anion (b). The peaks for chloride (1), nitrate (2), and sulfate (3) could be identified. Lactate (4) was used as an internal standard $\left(2.4 \mathrm{mg} \mathrm{L}^{-1}\right)$. Good peak resolution and baseline can be observed with MES/HIS/CTAH running buffer. The use of CTAH instead of CTAB for inversion of the electroosmotic flow avoids the negative peak ${ }^{13}$ associated to the bromide peak (from CTAB), which would reduce the sensitivity of chloride.

Figure 2 presents the electropherogram of ethanol fuel (a) and the same sample with addition of $1.94 \mathrm{mg} \mathrm{L}^{-1}$ of 

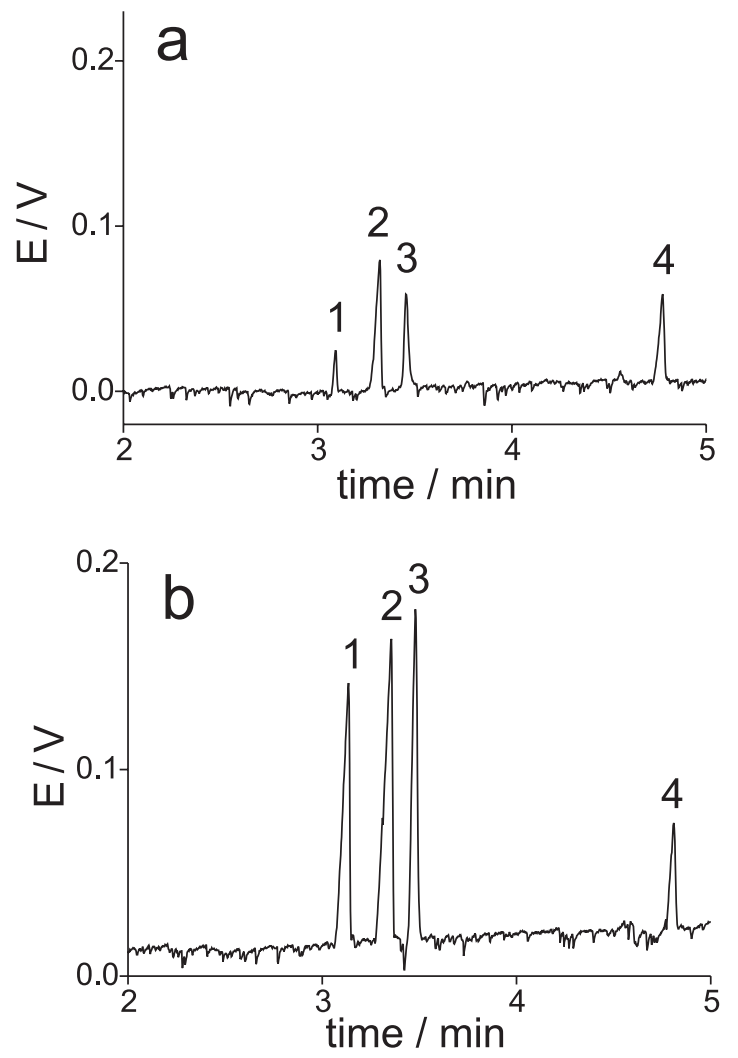

Figure 1. Separation of inorganic anions: (a) Electropherogram of ethanol sample: (b) Electropherogram of the same ethanol sample with addition of $1.94 \mathrm{mg} \mathrm{L}^{-1}$ of each analyte. Running buffer: 20 mmol L ${ }^{-1} \mathrm{MES} / \mathrm{HIS}$ and $0.2 \mathrm{mmol} \mathrm{L}^{-1} \mathrm{CTAH}$. Separation voltage -15 $\mathrm{kV}$; gravity injection at $100 \mathrm{~mm}$ for $30 \mathrm{~s}$; silica capillary with $75 \mathrm{~mm}$ inner diameter and $50 \mathrm{~cm}$ long; Peaks: (1) chloride, (2) nitrate, and (3) sulfate. Lactate (4) was used as internal standard $\left(2.4 \mathrm{mg} \mathrm{L}^{-1}\right)$.

each cation (b). The peaks for ammonium (1), potassium (2), sodium (3), calcium (4), and magnesium (5) were also identified. Lithium (6) was used as an internal standard (3 $\left.\mathrm{mg} \mathrm{L}^{-1}\right)$.

Table 2 shows the concentrations of anions and cations in two samples and the respective recoveries upon addition

Table 2. Concentration of anions and cations in two ethanol fuel samples and the respective recoveries ${ }^{\mathrm{a}}(\mathrm{n}=4)$

\begin{tabular}{lllll}
\hline Ions & $\begin{array}{l}\text { Sample A } \\
\text { Found }\end{array}$ & Recovery & $\begin{array}{l}\text { Sample B } \\
\text { Found }\end{array}$ & Recovery \\
\hline & $\left(\mathrm{mg} \mathrm{L}^{-1}\right)$ & $(\%)$ & $\left(\mathrm{mg} \mathrm{L}^{-1}\right)$ & $(\%)$ \\
$\mathrm{Cl}^{-}$ & $0.19 \pm 0.02$ & $101 \pm 5$ & $0.45 \pm 0.05$ & $98 \pm 6$ \\
$\mathrm{NO}_{3}^{-}$ & $2.30 \pm 0.10$ & $123 \pm 5$ & $3.51 \pm 0.18$ & $97 \pm 3$ \\
$\mathrm{SO}_{4}^{2-}$ & $0.98 \pm 0.03$ & $98 \pm 4$ & $0.48 \pm 0.05$ & $100 \pm 8$ \\
$\mathrm{NH}_{4}^{+}$ & $<\mathrm{LOD}$ & $97 \pm 4$ & $<\mathrm{LOD}$ & $117 \pm 6$ \\
$\mathrm{~K}^{+}$ & $0.63 \pm 0.06$ & $103 \pm 1$ & $0.49 \pm 0.06$ & $109 \pm 4$ \\
$\mathrm{Na}^{+}$ & $0.68 \pm 0.08$ & $96 \pm 5$ & $0.90 \pm 0.05$ & $95 \pm 3$ \\
$\mathrm{Ca}^{2+}$ & $<\mathrm{LOD}$ & $98 \pm 9$ & $0.94 \pm 0.08$ & $99 \pm 8$ \\
$\mathrm{Mg}^{2+}$ & $<\mathrm{LOD}$ & $99 \pm 3$ & $<$ LOD & $97 \pm 3$ \\
\hline
\end{tabular}

a addition of $1.94 \mathrm{mg} \mathrm{L}^{-1}$ of each ion.
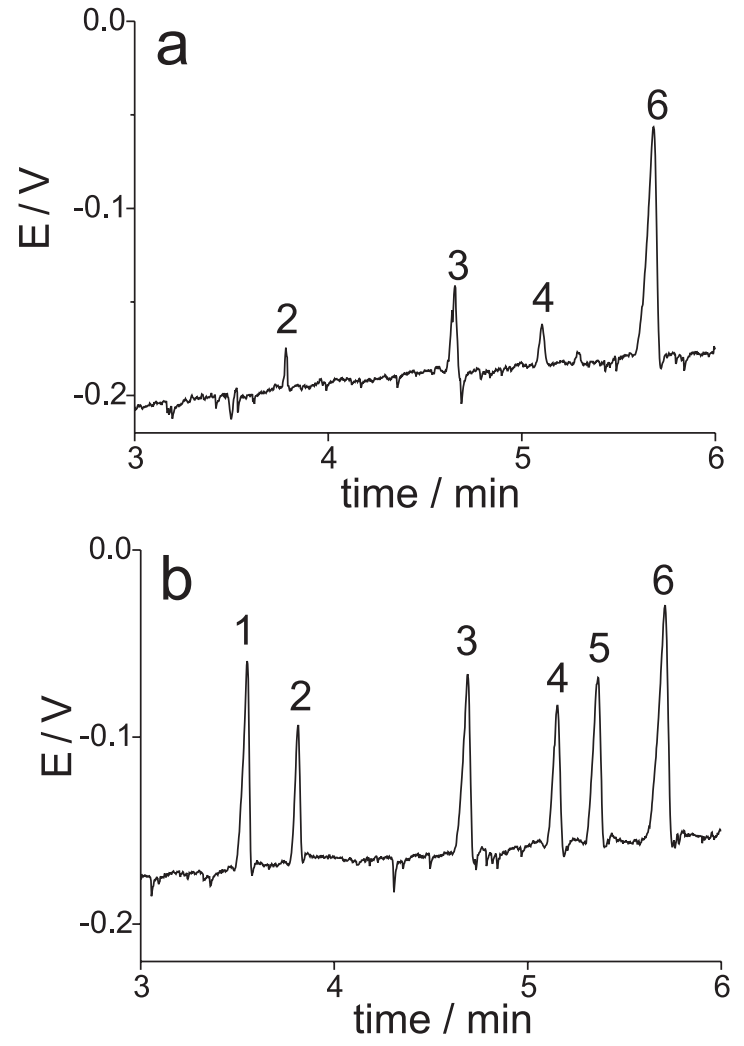

Figure 2. Separation of inorganic cations: (a) Electropherogram of ethanol sample: (b) Electropherogram of the same ethanol sample with addition of $1.94 \mathrm{mg} \mathrm{L}^{-1}$ of each analyte. Running buffer: 20 $\mathrm{mmol} \mathrm{L}{ }^{-1}$ lactic acid/HIS and $2.5 \mathrm{mmol} \mathrm{L}^{-1} 18$-crown-6-ether. Separation voltage $+15 \mathrm{kV}$; gravity injection at $100 \mathrm{~mm}$ for $30 \mathrm{~s}$; silica capillary with $75 \mathrm{~mm}$ inner diameter and $50 \mathrm{~cm}$ long; Peaks: (1) ammonium, (2) potassium, (3) sodium, (4) calcium, and (5) magnesium. Lithium (6) was used as internal standard $\left(3.0 \mathrm{mg} \mathrm{L}^{-1}\right)$.

of $1.94 \mathrm{mg} \mathrm{L}^{-1}$ of each ion. The concentrations of chloride, sulfate, and sodium in the two samples were below the upper limits established by ANP. The presence of the potassium and calcium ions in the samples can also cause similar engine problems as the sodium ions. Therefore, it is also important to check these ions in ethanol fuel.

Table 3 presents the analytical characteristics of the proposed method. It was observed a good linearity up to the highest standard solution utilized $\left(4 \mathrm{mg} \mathrm{L}^{-1}\right)$ in the analytical curves. However, this linearity is higher, but it was not evaluated in this work. It is important to emphasize that these limits of detection could be improved by using higher pressure and/or longer time of injection, without significant degradation of the electrophoretic separation.

\section{Conclusions}

Capillary electrophoresis with CCD was found to be very suitable for the determination of inorganic ions in ethanol fuel. The proposed method has lower cost and 
Table 3. Analytical characteristics of the proposed method

\begin{tabular}{|c|c|c|c|c|c|c|c|}
\hline Analytes & $\begin{array}{c}\mathrm{LOD}^{\mathrm{a}} \\
\left(\mathrm{mg} \mathrm{L}^{-1}\right)\end{array}$ & $\begin{array}{c}\mathrm{LOD}^{\mathrm{a}} \\
\left(\mathrm{mol} \mathrm{L}^{-1}\right)\end{array}$ & $\begin{array}{c}\mathrm{LOQ}^{\mathrm{b}} \\
\left(\mathrm{mg} \mathrm{L}^{-1}\right)\end{array}$ & $\begin{array}{c}\mathrm{LOQ}^{\mathrm{b}} \\
\left(\mathrm{mol} \mathrm{L}^{-1}\right)\end{array}$ & $\begin{array}{c}\text { Sensitivity } \\
\left(\mathrm{V} \text { min } \mathrm{mg} \mathrm{L}^{-1}\right)\end{array}$ & $\begin{array}{c}\text { Mobilities } \\
\left(10^{-8} \mathrm{~m}^{2} \mathrm{~V}^{-1} \mathrm{~s}^{-1}\right)\end{array}$ & $\mathrm{R}^{\mathrm{c}}$ \\
\hline $\mathrm{Cl}^{-}$ & 0.06 & $1.7 \times 10^{-6}$ & 0.20 & $5.6 \times 10^{-6}$ & $1.38 \pm 0.04$ & 5.73 & - \\
\hline $\mathrm{NO}_{3}^{-}$ & 0.08 & $1.3 \times 10^{-6}$ & 0.27 & $4.4 \times 10^{-6}$ & $0.72 \pm 0.02$ & 5.42 & 1.8 \\
\hline $\mathrm{SO}_{4}^{2-2}$ & 0.08 & $8.3 \times 10^{-7}$ & 0.27 & $2.8 \times 10^{-6}$ & $1.02 \pm 0.03$ & 5.18 & 1.6 \\
\hline $\mathrm{NH}_{4}^{+}$ & 0.12 & $6.7 \times 10^{-6}$ & 0.40 & $2.2 \times 10^{-5}$ & $0.22 \pm 0.01$ & 5.05 & - \\
\hline $\mathrm{K}^{+}{ }^{4}$ & 0.18 & $4.6 \times 10^{-6}$ & 0.60 & $1.5 \times 10^{-5}$ & $0.10 \pm 0.01$ & 4.69 & 3.6 \\
\hline $\mathrm{Na}^{+}$ & 0.13 & $5.6 \times 10^{-6}$ & 0.43 & $1.9 \times 10^{-5}$ & $0.13 \pm 0.01$ & 3.84 & 10.6 \\
\hline $\mathrm{Ca}^{2+}$ & 0.14 & $3.5 \times 10^{-6}$ & 0.47 & $1.2 \times 10^{-5}$ & $0.15 \pm 0.01$ & 3.49 & 5.3 \\
\hline $\mathrm{Mg}^{2+}$ & 0.14 & $5.8 \times 10^{-6}$ & 0.47 & $1.9 \times 10^{-5}$ & $0.23 \pm 0.01$ & 3.36 & 2.1 \\
\hline
\end{tabular}

${ }^{\mathrm{a}}$ for $\mathrm{SNR}=3 ;{ }^{\mathrm{b}}$ for $\mathrm{SNR}=10,{ }^{\mathrm{c}}$ Resolution between the corresponding peak and the previous one.

shorter analysis time, if compared to IC, despite the sample pretreatment step. The detection limits attained in the present study satisfy the upper limits established by ANP for ethanol fuel analysis.

\section{Acknowledgements}

The authors wish to thank FAPESP (Fundação de Amparo à Pesquisa do Estado de São Paulo), CNPq (Conselho Nacional de Desenvolvimento Científico e Tecnológico) and CNPq/CTPetro (process 502452/2003-0) for financial support.

\section{References}

1. http://www.anp.gov.br/anuario2002/apresentacao.html; accessed in July 2003.

2. Moreira, J.C.; Gushikem, Y.; Anal. Chim. Acta 1985, 176, 263.

3. Almeida, L.F.; Martins, V.L.; Silva, E.C.; Moreira, P.N.T.; Araújo, M.C.U.; J. Braz. Chem. Soc. 2003, 14, 249.

4. Oliveira, A.P.; Okumura, L.L.; Neto, J.A.G.; Moraes, M.; Eclet. Quim. 2002, 27, 285.

5. de Oliveira, A.P.; de Moraes, M; Neto, J.A.G.; Lima, E.C.; Atom. Spectrosc. 2002, 23, 39.

6. de Oliveira, A.P.; de Moraes, M; Neto, J.A.G.; Lima, E.C.; Atom. Spectrosc. 2002, 23, 190.

7. Pierre, T.S.; Aucélio, R.Q.; Curtius, A.J.; Microchem. J. 2003, $75,59$.
8. Pesco, C.; de Campos, E. A.; Costa, C. M. M.; Mikrochim. Acta 1997, 127, 229.

9. Gomes, L.A.M.; Padilha, P.M.; Moreira, J.C.; Filho, N.L.D.; Gushikem, Y.; J. Braz. Chem. Soc. 1998, 9, 494.

10. de Oliveira M.F.; Saczk, A.A.; Okumura, L.L.; Stradiotto, N.R.; Eclet. Quim. 2002, 27, 153.

11. ht t p://www.an p.gov.br/doc/portarias/2002/ Portaria_ANP_002_2002.pdf; accessed in July 2003.

12. Piatnicki, C.M.S.; Bockel, W.J.; Vilar, R.B.C.; Veses, R.C.; Samios, D.; Book of Abstracts of XII SIBEE (Simpósio Brasileiro de Eletroquímica e Eletroanalítica) 2002, p. 273.

13. Rocha, F.R.; da Silva, J.A.F.; do Lago, C.L.; Fornaro, A.; Gutz, I.G.R.; Atmos. Environ. 2003, 37, 105.

14. da Silva, J.A.F.; Ricelli, N.L.; Carvalho, A.Z.; do Lago, C.L.; J. Braz. Chem. Soc. 2003, 14, 265

15. da Silva, J.A.F.; Guzman, N.; do Lago, C.L.; J. Chrom. A 2002, 942, 249.

16. da Silva, J.A.F.; do Lago, C.L.; Anal. Chem. 1998, 70, 4339.

17. Bruning, I.M.R.A.; Malm, E.B.; Research and Development Center of Petrobras Company, Rio de Janeiro, 1980, 25, 15, apud ref. 9.

18. Bruning, I.M.R.A.; Malm, E.B.; Bol. Tec. Petrobras 1982, 25 , 217, apud ref. 9.

Received: August 12, 2003

Published on the web: June 18, 2004

FAPESP helped in meeting the publication costs of this article. 